\title{
PENGARUH PAD, DAU DAN DAK TERHADAP KEMANDIRIAN KEUANGAN DAERAH PROVINSI DI PULAU SUMATERA TAHUN 2010-2016
}

\author{
Puguh Setiawan $^{1}$, Rina Widiyanti $^{2}$, Liesma Maywarni Siregar $^{3}$, Nurhaida $^{4}$, Elmi Oktavia $^{5}$ \\ ${ }^{1,2,3,4,5)}$ Fakultas Ekonomi, Universitas Muhammadiyah Sumatera Barat, \\ ${ }^{1)}$ puguhstwn@gmail.com, ${ }^{2)}$ rinawidyanti99@yahoo.com ${ }^{3)}$ liesmamsiregar@gmail.com \\ ${ }^{4)}$ nurhaida@gmail.com ${ }^{5)}$ dee.okta7@gmail.com
}

\begin{abstract}
Nowadays the role of regional autonomy is increasing. Autonomy provides opportunities for regions to manage their finances independently and optimally. This study aims to reveal the effect of PAD, DAU and DAK on the regional financial independence. Using the panel data model, it was chosen that the best panel model for this study was the Fixed Effect Model. The results showed that only PAD had a positive effect on Regional Financial Independence, while DAU and DAK had no effect. DAU and DAK do not have a role in increasing Regional Financial Independence. This condition is understandable because the central government still determines and uses the DAU and DAK.
\end{abstract}

Keywords: PAD, DAU, DAK, Financial Independence

\begin{abstract}
Abstrak: Dewasa ini peran otonomi daerah semakin meningkat. Otonomi memberi kesempatan kepada Daerah untuk mengatur keuangannya secara mandiri dan maksimal. Penelitian ini bertujuan mengungkap pengaruh PAD, DAU dan DAK terhadap kemandirian keuangan daerah Propinsi. Menggunakan model data panel maka terpilih bahwa model panel terbaik untuk penelitian ini adalah Fixed Effect Model. Hasil penelitian menunjukkan bahwa hanya PAD yang memiliki pengaruh positif terhadap Kemandirian Keuangan Daerah, sementara DAU dan DAK tidak memiliki pengaruh. DAU dan DAK tidak memiliki peran dalam meningkatkan Kemandirian Keuangan Daerah. Kondisi ini dapat dipahami karena untuk pengelolaan dan penggunaan DAU dan DAK ini masih ditetapkan oleh Pemerintah Pusat.
\end{abstract}

Kata Kunci: $P A D, D A U, D A K$, Kemandirian Keuangan

\section{A. PENDAhUluan}

Kemandirian keuangan daerah tercermin pada pelaksanaan otonomi dan juga dapat diketahui melalui besarnya kemampuan sumber daya keuangan daerah digunakan untuk membangun daerahnya. Otonomi daerah di Indonesia dilaksanakan berdasarkan UndangUndang Nomor 22 Tahun 1999 tentang Pemerintahan Daerah dan Undang-Undang Nomor 25 Tahun 1999 tentang Perimbangan Keuangan antara Pemerintah Pusat dan Daerah, yang kemudian direvisi dengan Undang-Undang Nomor 32 Tahun 2004 tentang Pemerintahan Daerah terbaru dengan Undang-Undang Nomor 23 Tahun 2014 dan Undang-Undang Nomor 33 Tahun 2004 tentang Perimbangan Keuangan antara Pemerintah Pusat dan Daerah.

Suatu daerah yang otonom, harus mempunyai kemampuan keuangan dalam menyelenggarakan pemerintahan. Daerah yang telah mandiri ditandai dengan berkurangnya ketergantungan keuangan terhadap pusat. Meningkatkan pendapatan asli daerah merupakan salah satu cara dalam meningkatkan kemampuan keuangan pemerintah daerah dalam membiayai belanja rutin dan pembangunan. Semakin besar kontribusi PAD terhadap APBD maka semakin besar kemampuan daerah dalam melaksanakan otonomi.

Anggaran Pendapatan dan Belanja Daerah (APBD) merupakan salah satu instrumen kebijakan yang dipakai sebagai alat untuk meningkatkan pelayanan umum dan kesejahteraan masyarakat di daerah. Menurut Undang-Undang Nomor 17 Tahun 2003 tentang Keuangan Negara, Anggaran Pendapatan dan Belanja Daerah (APBD) adalah rencana keuangan tahunan pemerintahan daerah yang disetujui oleh Dewan Perwakilan Rakyat Daerah. Menurut Halim dan Kusufi (2012:21), Anggaran Pendapatan dan Belanja Daerah adalah rencana operasional keuangan pemerintah daerah yang menggambarkan perkiraan pengeluaran setinggi-tingginya guna membiayai kegiatan-kegiatan dan proyek-proyek daerah dalam satu tahun anggaran serta 
menggambarkan perkiraan penerimaan dan sumber penerimaan daerah untuk membiayai pengeluaran.

Penghitungan rasio kemandirian dan derajat desentralisasi fiskal pemerintah Provinsi sePulau Sumatera tahun 2014 disimpulkan bahwa total pendapatan asli daerah Provinsi di Pulau Sumatera sebesar 18,025 triliun dan total pendapatan daerah Provinsi se-Pulau Sumatera sebesar 51,22 triliun, sehingga diperoleh rata-rata derajat desentralisasi fiskal sebesar 35,19133\% dengan perolehan tertinggi pada Provinsi Sumatera Utara dan terendah pada Provinsi Aceh. Hal ini menunjukkan bahwa sepuluh Provinsi di Pulau Sumatera belum mampu menjalankan pemerintahan secara mandiri. Dana transfer dari Pemerintah Pusat menjadi penerimaan dominan dibandingkan PAD pada keuangan seluruh Provinsi di Pulau Sumatera (Febriantoko, 2017).

Hasil Penelitian Muliana (2009) menjelaskan bahwa Pendapatan Asli Daerah berpengaruh signifikan positif terhadap tingkat kemandirian keuangan daerah. Penelitian yang dilakukan oleh Tahar (2011) menunjukkan bahwa semakin tinggi PAD maka kemandirian keuangan daerah semakin meningkat, sementara semakin tinggi DAU maka kemandirian daerah akan semakin menurun. Hal ini menyatakan bahwa ketergantungan daerah terhadap bantuan Pemerintah Pusat menyebabkan penurunan kinerja pemerintah daerah. Penelitian Marizka (2013) menunjukkan bahwa semakin tinggi peningkatan PAD akan meningkatkan kemandirian keuangan daerah, sedangkan semakin tinggi DAK maka kemandirian daerah semakin rendah yang menunjukkan bahwa pemerintah daerah memiliki ketergantungan pendanaan dari Pemerintah Pusat. Penelitian Febriansyah (2015) menunjukkan adanya pengaruh peningkatan PAD terhadap kemandirian keuangan daerah sedangkan DAU dan DAK tidak berpengaruh pada kemandirian keuangan daerah.

Beragamnya hasil penelitian yang telah dilakukan oleh para peneliti terdahulu terkait hubungan antara PAD, DAU, DAK dan Kemandirian Keuangan Daerah dari beberapa wilayah di Indonesia menjadi hal yang sangat menarik untuk dikaji lebih mendalam tentang "Pengaruh PAD, DAU dan DAK Terhadap Kemandirian Keuangan Daerah Provinsi di Pulau Sumatera Data Tahun 2010-2016”.

\section{B. TINJAUAN PUSTAKA}

Sumber penerimaan daerah yang potensial harus digali secara maksimal, namun tentu saja masih di dalam peraturan perundang-undangan yang berlaku, termasuk diantaranya pajak daerah dan retribusi daerah yang memang menjadi unsur pendapatan asli daerah yang utama. Di era otonomi diharapkan daerah menjadi lebih mandiri di dalam pengelolaan kewenangannya yang ditandai dengan meningkatnya PAD suatu daerah. Sementera untuk beberapa hal, masih kekurangan dana, daerah masih diberi bantuan dari Pemerintah Pusat dalam bentuk dana perimbangan. Namun tujuan awal pelaksanaan otonomi adalah mewujudkan kapasitas fiskal daerah yang kuat dalam mendukung terciptanya kemandirian daerah (Mukarramah, 2017).

\section{Pendapatan Asli Daerah (PAD)}

Menurut Undang-Undang Nomor 33 Tahun 2004 tentang Perimbangan Keuangan antara Pemerintah Pusat dan Pemerintah Daerah, menyebutkan bahwa Pendapatan Asli Daerah adalah penerimaan yang diperoleh daerah yang dipungut berdasarkan peraturan daerah sesuai dengan peraturan perundang-undangan. Pendapatan Asli Daerah (PAD) merupakan sumber penerimaan daerah yang asli yang digali di daerah yang digunakan untuk modal dasar pemerintah daerah dalam membiayai pembangunan dan usaha-usaha daerah untuk memperkecil ketergantungan dana dari Pemerintah Pusat.

Menurut Halim dan Kusufi (2012:101) menyebutkan bahwa Pendapatan Asli Daerah merupakan semua penerimaan daerah yang berasal dari sumber ekonomi asli daerah. Klasifikasi PAD berdasarkan Permendagri Nomor 13 Tahun 2006 tentang Pedoman Pengelolaan Keuangan Daerah adalah pajak daerah, retribusi daerah, hasil pengelolaan kekayaan daerah yang dipisahkan dan lain-lain pendapatan asli daerah yang sah. 


\section{Dana Alokasi Umum (DAU)}

Dana Alokasi Umum merupakan salah satu bagian dari dana perimbangan yang ditujukan untuk mengurangi kesenjangan fiskal antar pemerintah daerah. Menurut Mardiasmo (2004:157) mengidentifikasi beberapa tujuan pemerintah yang memberikan dana bantuan dalam bentuk DAU kepada pemerintah daerah yaitu (1) untuk mendorong terciptanya keadilan antar wilayah (geographical equity), (2) untuk meningkatkan akuntabilitas (promote accountability), (3) untuk meningkatkan sistem pajak yang progresif karena pada riilnya masyarakat berpenghasilan rendah terbebani tarif pajak yang tinggi, dan (4) untuk meningkatkan keberterimaan (acceptability) pajak daerah yaitu dengan beberapa pengeluaran daerah untuk mengurangi jumlah pajak daerah.

Pembagian dana untuk daerah melalui bagi hasil berdasarkan daerah penghasil cenderung menimbulkan ketimpangan antar daerah dengan mempertimbangkan kebutuhan dan potensi daerah. DAU suatu daerah ditentukan atas besar kecilnya celah fiskal (fiscal gap) suatu daerah, yang merupakan selisih antara kebutuhan daerah (fiscal need) dan potensi daerah (fiscal capacity) dan dialokasikan dalam bentuk block grant. Dalam Undang-Undang Nomor 32 Tahun 2004 tentang Pemerintahan Daerah dan Undang-Undang Nomor 33 Tahun 2004 tentang Perimbangan Keuangan antara Pusat dan Daerah, ditegaskan kembali mengenai formula celah fiskal dan penambahan variabel DAU. Alokasi DAU bagi daerah yang potensi fiskalnya besar tetapi kebutuhan fiskalnya kecil akan memperoleh alokasi DAU yang kecil. Sebaliknya daerah yang potensi fiskalnya kecil namun kebutuhan fiskal besar akan memperoleh alokasi DAU yang besar. Bagi daerah yang tingkat kemiskinannya lebih tinggi, akan diberikan DAU lebih besar dibanding daerah yang kaya, dan begitu juga sebaliknya.

\section{Dana Alokasi Khusus (DAK)}

Menurut Undang-Undang Nomor 32 Tahun 2004 tentang Pemerintahan Daerah, Dana Alokasi Khusus (DAK) adalah dana yang bersumber dari pendapatan APBN yang dialokasikan kepada daerah tertentu dengan tujuan untuk mendanai kegiatan khusus yang merupakan urusan daerah dan sesuai dengan prioritas nasional. DAK dimaksudkan untuk membantu membiayai kegiatan-kegiatan khusus di daerah tertentu yang merupakan urusan daerah dan sesuai dengan prioritas nasional, khususnya untuk membiayai kebutuhan sarana dan prasarana masyarakat yang belum mencapai standar tertentu atau untuk mendorong percepatan pembangunan daerah. Karena itu alokasi yang didistribusikan oleh Pemerintah Pusat sepenuhnya merupakan wewenang pusat untuk tujuan nasional khusus.

DAK adalah bentuk dana yang bersifat khusus (specific grant), dimana penggunaan dana tersebut berdasarkan atas petunjuk atau kebijakan dari pihak pemberi (Pemerintah Pusat). Wilayah yang menerima DAK harus menyediakan dana penyesuaian paling tidak $10 \%$ dari DAK yang ditransfer ke wilayah, dan dana penyesuaian ini harus dianggarkan dalam anggaran daerah (APBD). Meski demikian, wilayah dengan pengeluaran lebih besar dari penerimaan tidak perlu menyediakan dana penyesuaian. Tetapi perlu diketahui bahwa tidak semua daerah menerima DAK karena DAK bertujuan untuk pemerataan dan untuk meningkatkan kondisi infrastruktur fisik yang dinilai sebagai prioritas nasional.

\section{$\underline{\text { Kemandirian Keuangan Daerah }}$}

Keberhasilan kemampuan keuangan daerah dalam melaksanakan otonomi daerah salah satunya dilihat dari kemandirian keuangan daerah tersebut. Artinya, pemerintah daerah otonom harus memiliki kewenangan dan kemampuan untuk menggali sumber-sumber keuangan sendiri, mengelola, dan menggunakan keuangan sendiri yang cukup memadai untuk membiayai penyelenggaraan pemerintahan daerahnya (Koswara dalam Tangkilisan, 2007:72). Bisma (2010:77) mengatakan bahwa analisis kinerja keuangan diukur melalui perhitungan rasio-rasio keuangan yang merupakan alat ukur kinerja keuangan.

Pengukuran kemampuan keuangan daerah bisa dilakukan dengan menghitung rasio-rasio keuangan. Halim (2004:284) mengatakan bahwa beberapa rasio yang dapat dikembangkan 
berdasarkan data keuangan yang bersumber dari APBD antara lain rasio kemandirian (otonomi fiskal), rasio efektivitas dan efisiensi, debt service ratio.

Rasio kemandirian keuangan daerah dihitung dengan cara membandingkan jumlah penerimaan pendapatan asli daerah dibagi dengan jumlah pendapatan transfer dari Pemerintah Pusat serta pinjaman daerah. semakin tinggi angka rasio ini menunjukkan pemerintah daerah semakin tinggi kemandirian keuangan daerahnya (Mahmudi, 2010:142). Tingkat kemandirian keuangan daerah adalah ukuran yang menunjukkan kemampuan keuangan pemerintah daerah dalam membiayai sendiri kegiatan pemerintahan, pembangunan dan pelayanan kepada masyarakat, yang diukur dengan rasio pendapatan asli daerah (PAD) terhadap jumlah bantuan Pemerintah Pusat dan pinjaman (Bisma, 2010:77).

Menurut Paul Hersey dan Kenneth Blanchard dalam Halim (2004:188), terdapat empat pola hubungan tingkat kemandirian daerah, yaitu:

1) Pola hubungan instruktif, yaitu peranan Pemerintah Pusat lebih dominan daripada pemerintah daerah.

2) Pola hubungan konsultatif, yaitu campur tangan Pemerintah Pusat semakin berkurang, karena daerah dianggap sudah mampu melaksanakan otonomi.

3) Pola hubungan partisipatif, yaitu peranan Pemerintah Pusat semakin berkurang, mengingat daerah yang bersangkutan tingkat kemandiriannya mendekati mampu melaksanakan urusan otonomi.

4) Pola hubungan delegatif, yaitu campur tangan Pemerintah Pusat, sudah tidak ada karena daerah telah benar-benar mampu dan mandiri dalam melaksanakan urusan daerah.

Lebih jelasnya, sebagai pedoman dalam melihat pola hubungan dengan kemampuan daerah dari sisi keuangan dapat dilihat pada tabel berikut:

Tabel Pola Hubungan dan Tingkat Kemampuan Daerah

\begin{tabular}{|l|c|c|}
\hline \multicolumn{1}{|c|}{$\begin{array}{c}\text { Kemampuan } \\
\text { Keuangan }\end{array}$} & $\begin{array}{c}\text { Rasio } \\
\text { Kemandirian }\end{array}$ & $\begin{array}{c}\text { Pola Hubungan Pusat- } \\
\text { Daerah Dalam Otonomi Daerah }\end{array}$ \\
\hline Rendah Sekali & $0 \%-25 \%$ & Instruktif \\
\hline Rendah & $>25 \%-50 \%$ & Konstruktif \\
\hline Sedang & $>50 \%-75 \%$ & Partisipatif \\
\hline Tinggi & $>75 \%-100 \%$ & Delegatif \\
\hline
\end{tabular}

Sumber: Halim, 2004

Kerangka Konseptual

Kerangka konseptual adalah penjelasan sementara terhadap suatu gejala yang menjadi objek permasalahan. Kerangka konseptual disusun dengan berdasarkan pada tinjauan pustaka dan hasil penelitian yang relevan atau terkait. Kerangka konseptual merupakan argumentasi dalam merumuskan hipotesis.

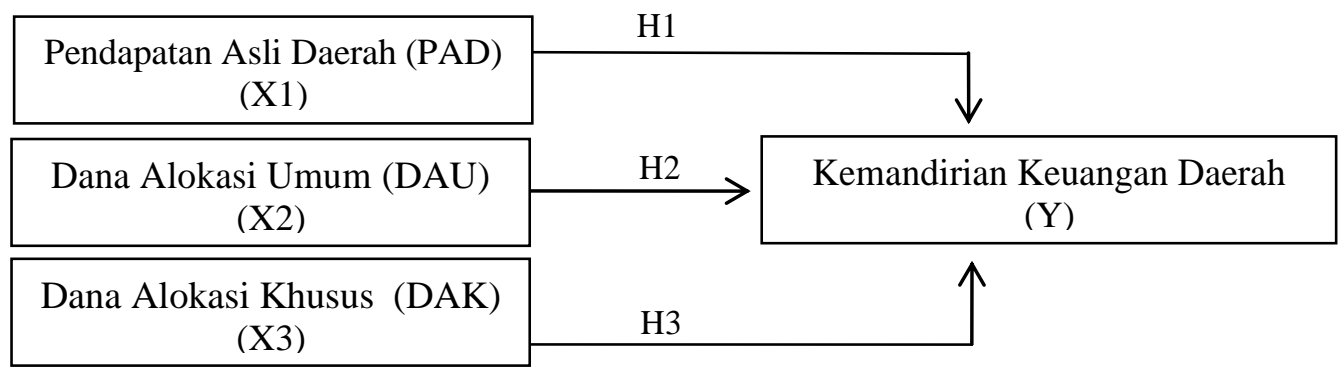

Hipotesis

Berdasarkan kerangka pemikiran di atas, maka penulis mencoba merumuskan hipotesis yang merupakan kesimpulan sementara dari penelitian, sebagai berikut:

H1 : Pendapatan Asli Daerah berpengaruh terhadap Kemandirian Keuangan Daerah Provinsi di Pulau Sumatera. 
H2 : Dana Alokasi Umum berpengaruh terhadap Kemandirian Keuangan Daerah Provinsi di Pulau Sumatera.

H3 : Dana Alokasi Khusus berpengaruh terhadap Kemandirian Keuangan Daerah Provinsi di Pulau Sumatera.

\section{METODE PENELITIAN}

Penelitian ini menggunakan E-Views 10 untuk mengolah 4 (empat) variabel yang terdiri dari 1 (satu) variabel dependen dan 3 (tiga) variabel independen. Variabel dependen dalam penelitian ini adalah Kemandirian Keuangan Daerah sedangkan variabel independennya adalah Pendapatan Asli Daerah, Dana Alokasi Umum dan Dana Alokasi Khusus.

Jenis penelitian ini merupakan penelitian kuantitatif yaitu penelitian yang menekankan pada pengujian teori-teori melalui pengukuran variabel-variabel penelitian dengan angka yang bertujuan untuk menguji hipotesis dan memperoleh jawaban atas hipotesis yang digunakan.

Populasi yang digunakan dalam penelitian ini berupa laporan realisasi APBD pemerintah Provinsi di Pulau Sumatera yang berjumlah 10 (sepuluh) Provinsi tahun 2010-2016. Sampel adalah bagian dari populasi, dalam penelitian ini yang dijadikan sampelnya adalah populasi itu sendiri, dengan alasan ketersediaan data dengan jumlah 10 Provinsi $x 7$ tahun $=70(\mathrm{~N})$.

Data diperoleh dari publikasi Direktorat Jenderal Perimbangan Keuangan (DJPK) Kementerian Keuangan RI dan data dari Badan Pusat Statistik (BPS). Berdasarkan waktu pengumpulannya, maka dalam penelitian ini data digolongkan pada time series dan cross section atau sering disebut dengan data panel. Data panel (panel pooled data) merupakan sekelompok data individual yang diteliti selama rentang waktu tertentu sehingga memberikan informasi observasi setiap individu dalam sampel. Keuntungan menggunakan panel data yaitu meningkatkan jumlah sampel populasi dan memperbesar degree of freedom serta penggabungan informasi yang berkaitan dengan variabel cross section dan time series.

Menurut Prahutama (2014:40), untuk mengestimasi parameter model dengan data panel, terdapat tiga teknik (model) pendekatan yang terdiri dari pendekatan umum (Common Effect), pendekatan efek tetap (Fixed Effect) dan pendekatan efek acak (Random Effect). Metode ini tidak menggunakan variabel dummy seperti yang digunakan pada metode fixed effect. Metode ini menggunakan residual yang diduga memiliki hubungan antar waktu dan antar objek. Pada dasarnya pemodelan data panel adalah penggabungan data time series dan cross section. Sehingga untuk analisis regresinya dinyatakan dengan rumus berikut ini :

$$
\begin{array}{ll}
\text { Yit } & =\alpha+\beta 1 \text { PADit }+\beta 2 D A U i t+\beta 3 D A K i t+\varepsilon i t \\
\text { Dimana : } & \\
\text { Yit } & : \text { Kemandirian Keuangan Daerah di Provinsi i pada tahun } \mathrm{t} \\
\alpha & : \text { Konstanta }(\text { intercept }) \\
\text { PADit } & : \text { Pendapatan Asli Daerah di Provinsi i pada tahun } \mathrm{t} \\
\text { DAUit } & : \text { Dana Alokasi Umum di Provinsi i pada tahun } \mathrm{t} \\
\text { DAKit } & : \text { Dana Alokasi Khusus di Provinsi i pada tahun } \mathrm{t} \\
\beta 1, \beta 2, \beta 3 & : \text { koefisien regresi } \\
\varepsilon & : \text { tingkat kesalahan (standard error) }
\end{array}
$$

Selanjutnya untuk mengetahui hasil hipotesis dilakukan dengan uji koefisien determinasi (R2) dan uji signifikansi parsial (uji-t). Pengujian hipotesis bertujuan untuk menentukan apakah hipotesis yang telah diajukan di terima atau di tolak..

\section{HASIL DAN PEMBAHASAN}

Pulau Sumatera berada di posisi $6^{\circ} \mathrm{LU}-6^{\circ} \mathrm{LS}$ dan antara $95^{\circ} \mathrm{BB}-109^{\circ} \mathrm{BT}$, merupakan pulau terbesar keenam di dunia. Pulau ini membujur dari barat laut ke arah tenggara dan melintasi khatulistiwa, Sumatera belahan bumi utara dan Sumatera belahan bumi selatan. Pegunungan Bukit Barisan dengan beberapa puncaknya yang melebihi 3.000 meter di atas permukaan laut merupakan barisan gunung berapi aktif, membentang sepanjang sisi barat dari ujung utara ke arah selatan, sehingga membuat dataran di sisi barat pulau relatif sempit dengan pantai yang 
terjal dan dalam ke arah Samudera Hindia dan dataran di sisi timur yang luas dan landai dengan pantai yang landai dan dangkal ke arah Selat Malaka, Selat Bangka dan Laut China Selatan.

Tabel Luas Daerah Menurut Provinsi di Pulau Sumatera Tahun 2017

\begin{tabular}{|l|l|c|c|}
\hline \multicolumn{1}{|c|}{ Provinsi } & \multicolumn{1}{|c|}{ Ibu Kota Provinsi } & Luas (KM2) & $\begin{array}{c}\text { Persentase terhadap } \\
\text { Luas Indonesia (\%) }\end{array}$ \\
\hline Aceh & Banda Aceh & $57.956,00$ & 3,20 \\
\hline Sumatera Utara & Medan & $72.981,23$ & 3,81 \\
\hline Sumatera Barat & Padang & $42.012,89$ & 2,19 \\
\hline Riau & Pekanbaru & $87.023,66$ & 4,54 \\
\hline Jambi & Jambi & $50.058,16$ & 2,61 \\
\hline Sumatera Selatan & Pelembang & $91.592,43$ & 4,78 \\
\hline Bengkulu & Bengkulu & $19.919,33$ & 1,04 \\
\hline Lampung & Bandar Lampung & $34.623,80$ & 1,81 \\
\hline Kepulauan Bangka Belitung & Pangkal Pinang & $16.424,06$ & 0,86 \\
\hline Kepulauan Riau & Tanjung Pinang & $8.201,72$ & 0,43 \\
\hline
\end{tabular}

Sumber: Diolah dari BPS, 2018

Berdasarkan sensus penduduk tahun 2010, Indonesia memiliki jumlah penduduk sebesar 237 juta jiwa, dan Sumatera merupakan daerah yang terpadat setelah Jawa. Pulau Sumatera dengan luas 25,2 persen dari luas seluruh wilayah Indonesia dihuni oleh 21,3 persen penduduk.

\begin{tabular}{|c|l|l|c|}
\hline No & \multicolumn{1}{|c|}{ Kota } & \multicolumn{1}{c|}{ Provinsi } & Populasi (Jiwa) \\
\hline 1 & Medan & Sumatera Utara & 2.465 .469 \\
\hline 2 & Palembang & Sumatera Selatan & 1.548 .064 \\
\hline 3 & Bandar LAmpung & Lampung & 1.166 .761 \\
\hline 4 & Pekanbaru & Riau & 1.093 .416 \\
\hline 5 & Batam & Kepulauan Riau & 1.035 .280 \\
\hline 6 & Padang & Sumatera Barat & 1.000 .096 \\
\hline 7 & Jambi & Jambi & 721.857 \\
\hline 8 & Bengkulu & Bengkulu & 373.243 \\
\hline 9 & Banda Aceh & Aceh & 287.769 \\
\hline 10 & Pematang Siantar & Sumatera Utara & 209.568 \\
\hline
\end{tabular}

Sumber: Wikipedia, 2018

Tabel Statistik Deskriptif

\begin{tabular}{lcccc}
\hline & KKD & PAD & DAU & DAK \\
\hline Mean & 73.04400 & 0.390061 & 0.256903 & 0.031193 \\
Median & 63.89500 & 0.388600 & 0.245050 & 0.012300 \\
Maximum & 260.4600 & 0.721700 & 0.522600 & 0.297300 \\
Minimum & 10.89000 & 0.098200 & 0.013700 & 0.002500 \\
Std. Dev. & 41.91442 & 0.122973 & 0.136643 & 0.062904 \\
Skewness & 1.757025 & -0.254183 & 0.438642 & 3.399622 \\
Kurtosis & 8.174867 & 3.688935 & 2.131452 & 13.25974 \\
Jarque-Bera & 114.1227 & 2.138114 & 4.445006 & 441.8516 \\
Probability & 0.000000 & 0.343332 & 0.108338 & 0.000000 \\
Sum & 5113.080 & 27.30430 & 17.98320 & 2.183500 \\
Sum Sq. Dev. & 121220.5 & 1.043437 & 1.288330 & 0.273025 \\
Observations & 70 & 70 & 70 & 70
\end{tabular}

Sumber : Output EViews 10

Estimasi Model Data Panel

a. Pendekatan Common Effect Model (CEM) 
Pengolahan data dengan metode pendekatan Common Effect Model sebagai salah satu syarat untuk melakukan uji F-restricted. Hasil regresinya adalah sebagai berikut :

\begin{tabular}{|l|c|}
\hline$R$-squared & 0.864450 \\
\hline Adjusted $R$-squared & 0.858288 \\
\hline
\end{tabular}

b. Pendekatan Fixed Effect Model (FEM)

Setelah itu dilakukan pengolahan data dengan metode pendekatan Fixed Effect Model untuk dibandingkan dengan metode pendekatan Common Effect Model pada uji F-restricted.

\begin{tabular}{|l|c|}
\hline$R$-squared & 0.940103 \\
\hline Adjusted $R$-squared & 0.927493 \\
\hline
\end{tabular}

c. Uji Chow (CEM dengan FEM)

Untuk mengetahui model data panel yang akan digunakan antara Common Effect Model atau Fixed Effect Model, digunakan uji F-Restricted dengan cara melihat nilai probabilitas $(P$ Value) F-statistik lebih kecil dari tingkat signifikansi $\alpha$ 5\%. Sebelum melihat nilai probabilitas $(P$-Value $)$ F-statistik, terlebih dahulu dibuat hipotesisnya sebagai berikut:

$\begin{array}{ccc}\mathrm{H} 0 & : & \text { Common Effect Model (Restricted) } \\ \mathrm{H} 1 & : & \text { Fixed Effect Model (Unrestricted) } \\ & & \text { Hasil Uji Chow }\end{array}$

Redundant Fixed Effects Tests

Equation: FIXED

Test cross-section fixed effects

\begin{tabular}{|l|r|r|c|}
\hline Effects Test & Statistic & D.f & Prob. \\
\hline \hline Coss-Section F & 7.999303 & $(9,57)$ & 0.0000 \\
\hline Cross-section Chi-square & 57.169875 & 9 & 0.0000 \\
\hline
\end{tabular}

Sumber: Output EViews 10 (data diolah)

Hasil Uji Chow diperoleh nilai F-statistik 7,999303 dengan nilai F-tabel pada df $(9,57)$ dan nilai probabilitas F-statistik sebesar 0,0000, yang artinya nilai probabilitas F-statistik lebih kecil dari tingkat signifikansi a 5\% $(0,0000<0,05)$. Maka H0 ditolak dan H1 diterima, sehingga model panel yang akan digunakan adalah Fixed Effect Model.

d. Uji Hausman (FEM dengan REM)

Uji Hausman adalah uji yang digunakan untuk menentukan metode terbaik antara Fixed Effect Model dengan Random Effect Model, dengan hipotesis sebagai berikut:

H0 : Random Effect Model

H1 : Fixed Effect Model

Correlated Random Effects - Hausman Test

Tabel Hasil Uji Hausman

Equation: Untitled

Test cross-section fixed effects

\begin{tabular}{|l|r|r|c|}
\hline Effeccts Test & Chi-Sq. Statistic & D.f & Prob. \\
\hline \hline Coss-Section Random & 7.573482 & 3 & 0.0557 \\
\hline
\end{tabular}

Sumber: Output EViews 10 (data diolah)

Hasil Uji Hausman menunjukkan Chi-Square Statistic sebesar 7,573482 dengan nilai probabilitas 0,0557 dan d.f. 3. Dikarenakan nilai probabilitas Chi-Square Statistic lebih besar dari $\alpha 5 \%(0,0557>0,05)$ maka H0 diterima, dan yang digunakan adalah Random Effect Model.

\section{e. Uji Lagrange Multiplier (REM dengan CEM)}

Uji Lagrange Multiplier atau biasa disebut juga dengan istilah Lagrangian Multiplier Test adalah analisis yang dilakukan dengan tujuan untuk menentukan metode yang terbaik dalam regresi data panel, apakah akan menggunakan common effect atau random effect.

Uji Lagrange Multiplier dengan eviews harus dilakukan jika berada pada dua kondisi saat melakukan regresi data panel, yaitu 
1. Uji Chow menunjukkan bahwa metode yang terbaik adalah common effect dari pada fixed effect. Sehingga langkah berikutnya untuk menentukan apakah common effect lebih baik dari random effect, maka diperlukan uji Lagrange Multiplier

2. Uji Hausman menunjukkan bahwa metode yang terbaik adalah random effect daripada fixed effect. Sehingga langkah berikutnya untuk menentukan apakah random effect lebih baik daripada common effect, maka dilakukan uji Lagrange Multiplier.

Pengujian ini dilakukan dengan hipotesis sebagai berikut:

$\mathrm{H} 0$ : Common Effect Model

$\mathrm{H} 1$ : Random Effect Model

Tabel Uji Lagrange Multiplier

Lagrange multiplier (LM) test for panel data

Sample: 20102016

Total panel observations: 70

Probability in ()

\begin{tabular}{|l|c|c|c|}
\hline $\begin{array}{l}\text { Null (no rand. effect) } \\
\text { Alternative }\end{array}$ & $\begin{array}{c}\text { Cross-section } \\
\text { One-sided }\end{array}$ & $\begin{array}{c}\text { Period } \\
\text { One-sided }\end{array}$ & Both \\
\hline \hline Breusch-Pagan & 32.14757 & 0.460137 & 32.60771 \\
\hline & $(0.0000)$ & $(0.4976)$ & $(0.0000)$ \\
\hline
\end{tabular}

Sumber: Output EViews 10 (data diolah)

Berdasarkan hasil Uji Lagrange Multiplier, nilai probability Breusch-Pagan (BP) sebesar 0,0000 lebih kecil dari taraf signifikansi $\alpha 5 \%(0,0000<0,05)$ maka $\mathrm{H} 0$ ditolak dan H1 diterima yang berarti model yang digunakan adalah Random Effect Model dengan data sebagai berikut :

\begin{tabular}{|c|c|c|c|}
\hline \multicolumn{1}{|c|}{ Variable } & Coefficient & t-Statistic & Prob. \\
\hline C & -62.87607 & & 0.0000 \\
\hline PAD & 361.8650 & 15.09656 & 0.0000 \\
\hline DAU & -15.51397 & -0.596906 & 0.5526 \\
\hline DAK & -39.87804 & -1.737520 & 0.0870 \\
\hline$R$-squared & 0.782272 & & \\
\hline Adjusted $R$-squared & 0.772375 & & \\
\hline F-statistic & 79.04347 & & \\
\hline Prob(F-statistic) & 0.000000 & & \\
\hline
\end{tabular}

Sumber: Output EViews 10 (data diolah)

Sehingga disimpulkan model regresi Random Effect Model dengan persamaan berikut:

$\mathrm{Y}=-62,87607+361,8650 \mathrm{PADit}-15,51397 \mathrm{DAUit}-39,87804 \mathrm{DAKit}+\varepsilon \mathrm{eit}$

Dimana :

Y :Kemandirian Keuangan Daerah

PADit : Pendapatan Asli Daerah di provinsi i pada periode $\mathrm{t}$

DAUit : Dana Alokasi Umum di provinsi i pada periode $t$

DAKit: Dana Alokasi Khusus di provinsi i pada periode t

Eit : Koefisien pengganggu/random error

Rangkaian pengujian diatas juga sekaligus menunjukkan hasil uji parsial (uji-t) dengan jabaran hasil pengujian sebagai berikut :

Pengaruh Pendapatan Asli Daerah (PAD) terhadap Kemandirian Keuangan Daerah.

Hasil uji hipotesis, PAD memiliki nilai koefisien sebesar 361,8650 dengan nilai t-hitung $15,09656>$ t-tabel $(1,997)$ dan tingkat signifikansi $0,000<0,05$ maka H0 ditolak dan H1 diterima. Dengan demikian dapat disimpulkan bahwa PAD berpengaruh signifikan positif terhadap Kemandirian Keuangan Daerah Provinsi di Sumatera, yang berarti semakin besar PAD maka semakin meningkat kemandirian keuangan daerah.

Hasil penelitian ini sesuai dengan penelitian yang telah dilakukan oleh Muliana (2009) yang menyimpulkan bahwa PAD berpengaruh signifikan positif terhadap kemandirian keuangan 
daerah. Penelitian yang dilakukan Marizka (2013) juga menemukan hasil yang sama menyatakan PAD berpengaruh signifikan positif terhadap kemandirian keuangan daerah.

\section{Pengaruh Dana Alokasi Umum (DAU) terhadap Kemandirian Keuangan Daerah.}

Hasil uji parsial (Uji-t) terhadap DAU menunjukkan koefisien regresi sebesar -15,51397 dengan t-hitung $-0,596906<\mathrm{t}$-tabel 1,997 dan tingkat signifikansi 0,5526 >0,05 maka H0 diterima dan H2 ditolak. Dapat disimpulkan bahwa Dana Alokasi Umum tidak memiliki pengaruh yang signifikan terhadap Kemandirian Keuangan Daerah.

Hasil penelitian ini sesuai dengan penelitian Marizka (2013) namun berlawanan hasilnya dengan penelitian Sari (2015) dan penelitian Nabila (2017) yang menyatakan bahwa DAU berpengaruh positif signifikan terhadap kemandirian keuangan daerah.

\section{Pengaruh Dana Alokasi Khusus (DAK) terhadap Kemandirian Keuangan Daerah.}

Hasil uji parsial (Uji-t) terhadap DAK menunjukkan koefisien regresi sebesar -39,87804 dengan t-hitung $-1,737520<$ t-tabel $(1,997)$ dan tingkat signifikansi $0,0870>0,05$ maka H0 diterima dan H3 ditolak. Sehingga dapat disimpulkan bahwa Dana Alokasi Khusus tidak memiliki pengaruh yang signifikan terhadap Kemandirian Keuangan Daerah.

Hal ini membuktikan bahwa seberapa besarpun dana alokasi khusus yang diterima oleh Pemerintah Provinsi di Pulau Sumatera tidak berpengaruh terhadap kemandirian keuangan daerah. Pelaksanaan DAK diarahkan pada kegiatan investasi pembangunan, pengadaan, peningkatan dan atau perbaikan sarana fisik masyarakat dengan umur ekonomis yang panjang. Hasil penelitian ini menunjukkan bahwa dana alokasi khusus tidak berpengaruh terhadap kemandirian keuangan daerah. Hal ini dikarenakan Pemerintah Daerah tidak mempunyai kewenangan untuk mengelola dan menggunakan dana alokasi khusus karena penggunaan dana alokasi khusus tersebut sudah ditetapkan oleh Pemerintah Pusat, sehingga Pemerintah Daerah hanya menjalankan sesuai dengan yang ditetapkan oleh Pemerintah Pusat.

Rekapan Hipotesis

\begin{tabular}{|c|l|c|}
\hline \multicolumn{1}{|c|}{ Hipotesis } & Hasil \\
\hline H1 & $\begin{array}{l}\text { Pendapatan Asli Daerah (PAD) berpengaruh terhadap Kemandirian } \\
\text { Keuangan Daerah Provinsi di Pulau Sumatera. }\end{array}$ & Diterima \\
\hline H2 & $\begin{array}{l}\text { Dana Alokasi Umum (DAU) berpengaruh terhadap Kemandirian } \\
\text { Keuangan Daerah Provinsi di Pulau Sumatera. }\end{array}$ & Ditolak \\
\hline H3 & $\begin{array}{l}\text { Dana Alokasi Khusus (DAK) berpengaruh terhadap Kemandirian } \\
\text { Keuangan Daerah Provinsi di Pulau Sumatera. }\end{array}$ & Ditolak \\
\hline
\end{tabular}

\section{E. PENUTUP}

Berdasarkan hasil pengujian yang telah dilakukan, maka kesimpulan yang dapat diambil dari penelitian ini adalah sebagai berikut :

1. Pendapatan Asli Daerah berpengaruh signifikan positif terhadap kemandirian keuangan daerah pada provinsi di Pulau Sumatera. Semakin besar pendapatan asli daerah maka semakin meningkat kemandirian keuangan daerah atau sebaliknya. Hal ini berdasarkan hasil uji-t diketahui bahwa nilai signifikansi lebih kecil dari tingkat keyakinan $\alpha 5 \%$ yakni $0,000<$ 0,05 .

2. Dana Alokasi Umum dan Dana Alokasi Khusus tidak berpengaruh terhadap kemandirian keuangan daerah pada provinsi di Pulau Sumatera. Berdasarkan hasil uji-t diketahui bahwa nilai signifikansi Dana Alokasi Umum dan Dana Alokasi Khusus lebih besar dari tingkat keyakinan $\alpha 5 \%$. Besar kecilnya perubahan yang terjadi pada Dana Alokasi Umum dan Dana Alokasi Khusus tidak memiliki peran dalam meningkatkan Kemandirian Keuangan Daerah Provinsi.

3. Hasil uji koefisien determinasi (R2) sebesar sebesar 0,782272 menunjukkan bahwa 78,22\% Kemandirian Keuangan Daerah Provinsi di Pulau Sumatera dipengaruhi oleh variabel 
Pendapatan Asli Daerah, Dana Alokasi Umum dan Dana Alokasi Khusus, sedangkan sisanya $21,78 \%$ dipengaruhi oleh variabel lain yang tidak diteliti dalam penelitian ini.

Penelitian ini mempunyai beberapa keterbatasan yang dapat menjadi pertimbangan bagi peneliti berikutnya agar mendapatkan hasil penelitian yang lebih baik. Keterbatasan tersebut antara lain :

1. Sampel yang digunakan hanya fokus pada pemerintah provinsi di Pulau Sumatera, sehingga hasil penelitian belum bisa digeneralisasi.

2. Penelitian ini menggunakan data sekunder, tidak dilengkapi data-data primer seperti kuesioner/wawancara sehingga menjadikan penelitian belum optimal.

3. Keterbatasan jumlah variabel atau aspek penelitian yang mempengaruhi kemandirian keuangan daerah, karena masih banyak aspek yang bisa mempengaruhi kemandirian keuangan daerah selain variabel yang digunakan dalam penelitian ini.

Adapun saran yang dapat disampaikan berdasar hasil penelitian yaitu :

1. Penelitian selanjutnya diharapkan dapat menguji dan menambah variabel lain yang mempengaruhi kemandirian keuangan daerah serta menambah sampel peneltian, misalnya dengan meneliti seluruh pemerintah provinsi di Indonesia sehingga hasilnya lebih akurat.

2. Pemerintah Provinsi di Pulau Sumatera diharapkan bisa lebih menggali potensi pendapatan asli daerahnya dengan meningkatkan hasil pajak daerahnya, hasil retribusi daerah, hasil pengelolaan kekayaan daerah yang dipisahkan dan lain-lain pendapatan asli daerah yang sah.

\section{F. DAFTAR PUSTAKA}

Bisma, I Dewa Gde dan Susanto Hery, (2010). Evaluasi Kinerja Keuangan Daerah Pemerintah Provinsi Nusa Tenggara Barat Tahun Anggaran 2003-2007. Ganec Swara Edisi Khusus Universitas Mataram, Vol. 04 No. 03 Hal 75-86.

Febriansyah, Abdullah (2015). Pengaruh Pendapatan Asli Daerah, Dana Alokasi Umum dan Dana Alokasi Khusus terhadap Kinerja Keuangan Pemerintah Daerah Kabupaten/Kota se-Sumatera Bagian Selatan. Artikel Ilmiah. Universitas Bengkulu.

Febriantoko, Jovan (2017). Analisis Kemampuan Keuangan dalam Penyelenggaraan Pemerintah Daerah Provinsi di Pulau Sumatera. Jurnal Akuntansi. Palembang: STMIK-Politeknik Palcomtech.

Halim, Abdul dan Kusufi (2012). Akuntansi Sektor Publik, Teori, Konsep dan Aplikasi. Jakarta: Salemba Empat.

Mahmudi (2010). Manajemen Kinerja Sektor Publik. Edisi Kedua. Yogyakarta: UPP STIM YKPN.

Mardiasmo (2004). Otonomi dan Manajemen Keuangan Daerah. Yogyakarta: Penerbit Andi.

Marizka Reza, (2013). Pengaruh Pendapatan Asli Daerah, Dana Bagi Hasil, Dana Alokasi Umum dan Dana Alokasi Khusus terhadap Kemandirian Daerah pada Kabupaten dan Kota di Sumatera Barat (Tahun 2006-2011). Jurnal Akuntansi. Universitas Negeri Padang.

Mukarramah Habibatul, (2017). Pengaruh Pajak Daerah dan Retribusi Daerah terhadap Kemandirian Keuangan Daerah di Lima Kabupaten/Kota Provinsi Jawa Barat Tahun 2008-2014. Skripsi. Jakarta: Universitas Islam Negeri Syarif Hidayatullah.

Muliana, (2009). Pengaruh Rasio Efektifitas PAD, DAU dan DAK terhadap Tingkat Kemandirian Keuangan Daerah. Artikel Ilmiah. Universitas Sumatera Utara.

Prahutama, Alan dkk. (2014). Modul Praktikum Ekonometrika. Fakultas Sains dan Matematika. Semarang: Universitas Diponegoro.

Tahar, Afrizal dan Maulida Zakhiya. (2011). Pengaruh Pendapatan Asli Daerah dan Dana Alokasi Umum terhadap Kemandirian Daerah dan Pertumbuhan Ekonomi Daerah. Jurnal Akuntansi. Universitas Muhammadiyah Yogyakarta.

Tangkilisan, Hessel Nogi S. (2007). Manajemen Publik. Jakarta: Grasindo. 